\title{
TAXation Of The PUblic SeCtor IN GERMANY - AN INTRODUCTION
}

\author{
FRITZ LANG*
}

\section{INTRODUCTION}

This paper reproduces the content of the author's presentation to "Current research problems in administrative studies in Poland and Germany" conference held at the University of Wrocław on 21-22 October 2016. It illustrates the fundamental methods and problems concerning taxation of the public sector in Germany based on the examples of corporation tax and value-added tax.

\section{DEFINITION "ÖFFENTLICHE HAND"}

The German-language term "öffentliche Hand" is essentially a colloquial designation ${ }^{1}$ for the public sector that, as a legal concept, is indeterminate in terms of both definition and interpretation. For taxation purposes, the concept is more specifically understood to include legal entities governed by public law ("legal entities of public law" or "l.e.p.l.", in German: "juristische Personen des öffentlichen Rechts" or "jPöR" for short). This encompasses primarily public authorities (e.g. the federal government, federal states, districts, municipalities, municipal associations), publicsector associations, religious affiliations under public law, guilds, chambers of craft and trade, chambers of industry and commerce, and institutions and foundations established under public law, e.g. public service broadcasters. ${ }^{2}$ Public law status may be conferred by federal or state law. The fundamental tasks of a legal entity of public law (l.e.p.1.) lie in the exercise of public authority for the performance of sovereign functions.

\footnotetext{
DOI: $10.1515 /$ wrlae-2015-0055

* Professor for Income Tax Law and International Fiscal Law, Head of Department of Tax Administration, Meissen University of Applied Administrative Sciences, Centre for Continuing Education; fritz.lang@hsf.sachsen.de

${ }^{1}$ However, the term is also used in legislation to a limited extent as an indeterminate legal concept, e.g. in sec 141 of the Ninth Book of the German Social Security Code (SGB IX), which refers to "Aufträge der öffentlichen Hand" (public-sector contracts).

2 cf. sec 4.1 of the Corporation Tax Guidelines 2015 (KStR 2015). Note: The KStR/KStH are administrative instructions developed by the German Federal Ministry of Finance (BMF) in conjunction with the federal states and published by the BMF.
} 


\section{THE INCOME TAX TREATMENT OF LEGAL ENTITIES GOVERNED by Public Law}

\section{TAXATION OF ECONOMIC ACTIVITIES ONLY}

To the extent that a legal entity of public law (1.e.p.1.) performs the sovereign functions assigned to it, it is generally exempt from income tax. ${ }^{3}$ Activities of this nature are not consistent with the underlying principle of income tax law, namely the taxation of activities aimed at generating income. To the extent that a legal entity of public law (1.e.p.1.) performs activities that are not reserved for it by custom and by law ${ }^{4}$ but that can also be performed by private individuals, however, this places it in competition with the free economy, meaning that it must be taxed in order to ensure the equal treatment of these activities. As such, taxation is intended to prevent the distortion of competition and ensure fair competition.

\section{UNLIMITED TAX LIABILITY}

In accordance with para $1 \mathrm{sec} 1$ no 6 Corporation Tax Act (KStG for short), only the commercial operations ("Betriebe gewerblicher Art" or "BgA" for short) of a domestic ${ }^{5}$ legal entity of public law (1.e.p.1.) within the meaning of para 4 Corporation Tax Act (KStG) are subject to unlimited corporation tax liability ${ }^{6}$. This means that unlimited tax liability often only relates to a limited portion of a legal entity of public law (1.e.p.1.) that gives the outward appearance of a commercial operation. ${ }^{7}$ However, the taxable entity, as such, is not the BgA but the legal entity of public law (1.e.p.l.), and specifically for each individual $\mathrm{BgA}$ it operates. ${ }^{8}$ As a matter of principle, different activities must be evaluated separately and the resulting income calculated separately. ${ }^{9}$ Tax assessment for each individual $\mathrm{BgA}$ is

\footnotetext{
3 "Sovereign operations" are explicitly discussed in sec 4 (5) sentence 1 of the German Corporation Tax Act (KStG) of 22 April 1999 (BGB1. I 1999, 817), most recently amended by the German Investment Tax Reform Act (InvStRefG) of 19 July 2016, BGB1. I 2016, 1730 .

4 cf. sec 4.4 "Sovereign operations/exercise of public authority" of the Corporation Tax Information 2015 (KStH 2015).

5 cf. sec 1.1 (3) sentence 2 Corporation Tax Guidelines 2015 (KStR 2015) - by contrast, the corporation tax liability of a foreign legal entity of public law (1.e.p.1.) is governed by para $2 \mathrm{sec} 1$ Corporation Tax Act / KStG (= limited tax liability in respect of income generated in Germany).

${ }^{6}$ In Germany, the taxation of the income of entities (including entities governed by public law (jPöRs) is governed by the provisions of the Corporation Tax Act / KStG. By contrast, the income of natural persons is governed by the provisions of the German Income Tax Act (EStG).

7 cf. German Federal Finance Court (BFH), verdict of 22 September 1976, I R 102/74, BStB1. II 1976, 793.

${ }^{8}$ cf. German Federal Finance Court (BFH), verdict of 13 March 1974, I R 7/71, BStB1. II $1974,391$.

${ }^{9}$ cf. para $4 \sec 6$ Corporation Tax Act / KStG - BgAs may be combined under certain conditions (for more information see German Federal Ministry of Finance (BMF), circular
} 
performed with respect to the legal entity of public law (1.e.p.l.) as the taxable entity. ${ }^{10}$

\section{LIMITED TAX LIABILITY}

One special feature of legal entities of public law (1.e.p.l.) taxation is that a legal entity of public law (l.e.p.l.) may be subject to unlimited corporation tax liability and limited corporation tax liability simultaneously. ${ }^{11}$ If the activities of a legal entity of public law (1.e.p.1.) fail to meet the conditions for classification as a $\mathrm{BgA}$, they are generally not taxable at the level of the legal entity of public law (1.e.p.1.). In particular, this benefits the area of asset management in the form of rental and lease income (para 21 Income Tax Act (EStG for short) or income from capital assets (para 20 Income Tax Act (EStG). As an exception, para 2 no 2 Corporation Tax Act (KStG) states that a legal entity of public law (1.e.p.l.) with domestic income ${ }^{12}$ that is fully or partially tax-deductible is subject to limited corporation tax liability. This relates primarily to income from capital assets, as these are generally subject to the provisions on the deductibility of capital gains tax in accordance with para $43 \mathrm{ff}$. Income Tax Act (EStG). Income covered by para 50a Income Tax Act (EStG) also comes into consideration to a limited extent. The tax deduction is definitive in accordance with para $32 \mathrm{sec} 1$ no 2 Corporation Tax Act (KStG).

\section{Commercial Operations (BGA)}

\subsection{DEFINITION}

In accordance with para 1 sec 1 no 6 Corporation Tax Act (KStG), a legal entity of public law (l.e.p.l.) is subject to unlimited corporation tax liability only to the extent that it conducts commercial operations ("Betriebe

of 12 November 2009, IV C 7 - S 2706/08/10004, BStB1. I 2009, 1303 under A. Combining BgAs.

${ }^{10}$ This presents an interesting difference compared with the treatment for value-added tax purposes. A legal entity of public law (l.e.p.l.) can only be a single entrepreneur under German value-added tax law (cf. sec 2 of the German Value-Added tax Act (UStG). In this case, the entity encompasses all of the legal entity of public law (1.e.p.1.)'s activities and must be registered under a single tax number.

11 Note: In accordance with the provisions of para 1 Income Tax Act (EStG), natural persons may not be simultaneously subject to unlimited tax liability for certain income and limited tax liability for other income. At most, their tax liability status may change during the course of the year. In accordance with paras 1, 2 Corporation Tax Act / KStG, the same applies e.g. to corporations.

${ }^{12}$ cf. para 8 sec 1 sentence 1 Corporation Tax Act / KStG: The definition of income is governed by the provisions of the Income Tax Act (EStG) and the Corporation Tax Act $(\mathrm{KStG})$. Opinion is divided as to whether para 2 no 2 Corporation Tax Act / KStG defines a limitation on the income specified in para 49 Income Tax Act (EStG) (affirmative: Gerrit Frotscher in Gerrit Frotscher, Klaus-Dieter Drüen, Corporation Tax Act / KStG (HaufeLexware GmbH \& Co. KG 2008) para 2 Corporation Tax Act / KStG m.n. 28; negative: Sven-Christian Witt in Carl Herrmann, Gerhard Heuer, Arndt Raupach, Income Tax Act (EStG)/Corporation Tax Act (KStG) (21st ed. Verlag Dr. Otto Schmidt KG 2006), 275th instalment, June 2016, para 2 Corporation Tax Act / KStG, m.n. 105). 
gewerblicher Art" or "BgA" for short). ${ }^{13}$ In accordance with para 4 sec 1 sentence 1 Corporation Tax Act ( $\mathrm{KStG})$, this is the case if: a) a body ("Einrichtung") exists that b) performs a sustainable economic activity c) in order to generate income and that d) is economically distinct within the overall activity of the legal entity of public law (1.e.p.l.). ${ }^{14}$

\section{2. "EINRICHTUNG"}

"Einrichtung" is an indeterminate legal concept whose interpretation is based primarily on the judgements issued by the German Federal Finance Court (BFH). Accordingly, an "Einrichtung" may be deemed to exist on the basis of a specific management team, a closed scope of business, accounting or another characteristic suggesting the existence of a separate entity. ${ }^{15}$ Economic independence may also be suggested by characteristics other than organisational characteristics. ${ }^{16}$ The level of revenue generated from the economic activity may also be a relevant factor. ${ }^{17}$ In sec 4.1 (4) sentence 2 Corporation Tax Guidelines 2015 (KStR 2015), the authorities define a threshold for the latter as annual revenue of EUR 130,000 within the meaning of para $1 \mathrm{sec} 1$ no 1 Value Added Tax Act (Umsatzsteuergesetz; UStG for short). The threshold is particularly relevant in cases where the activity of the legal entity of public law (1.e.p.l.) is not already clearly delineated from the other activities at an organisational level, e.g. in the case of a public undertaking ("Regiebetrieb") of a municipality. ${ }^{18}$

\subsection{Sustainable ECONOMic ACtivity}

In income tax law, tax-relevant activities are typically defined by reference to the sustainability principle. The concept described in para $4 \mathrm{sec}$

\footnotetext{
13 Note: Unlimited tax liability continues to apply in accordance with para $4 \mathrm{sec} 2$ Corporation Tax Act / KStG even if the $\mathrm{BgA}$ is itself a legal entity of public law (1.e.p.1.). Typical examples include district or municipal savings banks under public ownership (whose primary purpose is private economic enterprise), which are subject to the provisions of para $1 \mathrm{sec} 1$ no 6 Corporation Tax Act / KStG despite themselves being a legal entity of public law (1.e.p.1.).

${ }^{14}$ Note: As a matter of principle, public utilities (water, gas, electricity, heat), public transport undertakings and port authorities constitute BgAs in accordance with para 4 sec 3 Corporation Tax Act / KStG.

15 cf. German Federal Finance Court (BFH), verdict of 26 May 1977, V R 15/74, BStB1. II $1974,813$.

${ }^{16}$ cf. German Federal Finance Court (BFH), verdict of 13 March 1974, I R 7/71, BStB1. II $1974,391$.

17 cf. German Federal Finance Court (BFH), verdict of 26 February 1957, I R 327/56 U, BStB1. II 1957, 146.

${ }^{18}$ A "Regiebetrieb" is an unincorporated, legally and economically dependent branch of a municipality that is integrated into the municipal budget. It is distinct from e.g. a municipal enterprise (cf. e.g. para $95 \mathrm{sec} 1$ no 2 and para 95a of the Municipal Code for the Free State of Saxony (SächsGemO) in the version published on 3 March 2014, SächsGVB1. 2014, 146, and the Regulation on Municipal Enterprises of the Free State of Saxony (SächsEigBVO) of 16 December 2013, SächsGVB1. 2013, 941), which is also unincorporated but which constitutes an independent municipal body in terms of both organisation and budget.
} 
1 sentence 1 Corporation Tax Act $(\mathrm{KStG})$ is the same as the concept described in para $15 \mathrm{sec} 2$ sentence 1 Income Tax Act (EStG). ${ }^{19}$ An activity is considered to be sustainable if it is intended to be a repeated activity. This intention is an internal fact that must be verified by reference to external circumstances. Accordingly, if similar actions are actually repeated, an activity can generally be considered to be sustainable. However, a one-off activity that is evidently intended to be a repeated activity may be sufficient for classification as sustainable. ${ }^{20}$

The economic activity of the legal entity of public law (1.e.p.1.) must go beyond pure asset management. The statements by the authorities in sec 15.7 of the Income Tax Guidelines (EStR) 2012 can be applied for definition purposes. ${ }^{21}$ For example, a municipality does not establish a BgA merely by transferring land for use in exchange for a fee without the performance of any additional services ${ }^{22}$ or by generating income from capital assets $^{23}$. Although economic activities are generally performed in competition with other market participants, para 4 sec 1 sentence 2 Corporation Tax Act (KStG) states that participation in the free economy ${ }^{24}$ is not a prerequisite. Monopoly status may give rise to a $\mathrm{BgA}$ under certain circumstances, e.g. the granting of assigned pitches at a market event. ${ }^{25}$ This means that a self-sufficient undertaking ("Selbstversorgerbetrieb") may also be a $\mathrm{BgA}$. Although the economic activities of a legal entity of public law (1.e.p.l.) are evaluated separately as a matter of principle, different activities in accordance with sec 4.1 (3) sentence 3 Corporation Tax Guidelines 2015 (KStR 2015) are also treated as a single entity if this is consistent with prevailing opinion.

\subsection{GENERATION OF INCOME}

In accordance with para 4 sec 1 sentence 2 Corporation Tax Act $(\mathrm{KStG})$, the intention to make a profit ${ }^{26}$ is not necessary. para $4 \mathrm{sec} 1$

\footnotetext{
19 cf. Norbert Meier, Thomas Semelka in Carl Herrmann, Gerhard Heuer, Arndt Raupach (eds), Income Tax Act (EStG)/Corporation Tax Act (KStG) (21st ed. Verlag Dr. Otto Schmidt KG 2006), 275th instalment, June 2016, sec Corporation Tax Act / KStG, m.n. 23. ${ }^{20} \mathrm{cf}$. sec 15.2 of the Income Tax Information (EStH) and BFH, verdict of 31 July 1990, I R 173/83, BStB1 II 1991, 66.

${ }^{21}$ cf. Meier, Semelka (n 20) para 4 Corporation Tax Act / KStG, m.n. 28.

${ }^{22}$ Note: However, the formation of separate companies using legal forms such as the $\mathrm{GmbH}$ (limited liability company under German law) is often encountered in the area of residential letting in particular. The income generated by these companies is generally taxable in accordance with sec 1 (1) no 1 Corporation Tax Act / KStG.

${ }^{23}$ Note: However, cf. also sec 3.3; limited tax liability may exist in this respect.

24 To this extent, a BgA may make use of a special variation of the criteria for the delimitation of types of profit income that would otherwise apply in accordance with para $15 \mathrm{sec} 2$ sentence 1 Income Tax Act / EStG for short.

${ }^{25}$ cf. sec 4.5 Corporation Tax Information 2015 (KStH 2015), "Market events (weekly and second-hand markets)".

${ }^{26}$ Note: In this respect - in the same way as for the requirement of participation in the free economy (see sec 3.4.3) - the Corporation Tax Act / KStG deviates from the basic requirements that otherwise apply to commercial operations in accordance with para $15 \mathrm{sec}$ 2 sentence 1 Income Tax Act / EStG. This may have consequences for the trade tax liability of the $\mathrm{BgA}$. In accordance with para $2 \mathrm{sec} 1$ sentence 2 of the German Trade Tax Act
} 
sentence 1 Corporation Tax Act $(\mathrm{KStG})$ states that the intention to generate income is sufficient. The generation of income is not required to be the primary objective of the activity, but can also be an ancillary objective. ${ }^{27}$ The term "income" corresponds to the definition in para 8 sec 1 Income Tax Act (EStG), meaning that it includes cash as well as non-cash benefits. Income from economic activities includes fees charged in this context ${ }^{28}$.

\subsection{ECONOMIC WEIGHT}

One of the characteristics of a $\mathrm{BgA}$ is that its activity must be distinct within the overall activity of the legal entity of public law (1.e.p.l.). However, the benchmark to be applied in this respect is debatable. It can certainly be asserted that the authorities do not follow the case law established by the German Federal Finance Court, which states that the ratio of the BgA's income to the total budget, or a certain portion of the total budget, of the legal entity of public law (1.e.p.1.) may be a relevant benchmark $^{29}$. The benchmark defined by the authorities in sec 4.1 (5) sentence 1 Corporation Tax Guidelines 2015 (KStR 2015) is whether the annual revenue of the $\mathrm{BgA}$ within the meaning of para $1 \mathrm{sec} 1$ no 1 Value Added Tax Act (UStG) sustainably exceeds EUR 35,000. However, this does not represent a fixed threshold ${ }^{30}$.

\subsection{DEFINITION "HOHEITSBETRIEB"}

In accordance with para $4 \sec 5$ sentence 1 Corporation Tax Act (KStG), the operations of a legal entity of public law (1.e.p.l.) that are aimed primarily at the exercise of public authority, known as "Hoheitsbetriebe"

(GewStG), a commercial operation with a permanent domicile is subject to taxation, whereby a commercial operation is defined within the meaning of the Income Tax Act / EStG - including the intention to generate a profit and participation in the free economy. cf. Marion Frotscher in Gerrit Frotscher, Klaus-Dieter Drüen, German Trade Tax Act / GewStG, para 2 GewStG, m.n. 50, Haufe-Lexware GmbH \& Co. KG Freiburg, Steuer Office Kanzlei-Ed., version dated 6 September 2012; sec 2.1 (6) of the Trade Tax Guidelines (GewStR). Para $8 \mathrm{sec} 1$ sentence 2 contains a provision with the same wording. As the intention to generate a profit is not a prerequisite, the principles of income tax law concerning hobby activities do not apply and it is possible for a BgA to be permanently loss-making (cf. Ulrich Schallmoser in Carl Herrmann, Gerhard Heuer, Arndt Raupach, Income Tax Act (EStG)/Corporation Tax Act (KStG) (Verlag Dr. Otto Schmidt KG Köln 2006), 275th instalment, June 2016, para 8 Corporation Tax Act / KStG, m.n. 28). Also of interest in this respect is the provision of para $8 \mathrm{sec} 7$ Corporation Tax Act / KStG negating the existence of a concealed profit distribution for permanently loss-making operations under certain circumstances.

${ }^{27}$ cf. German Federal Finance Court (BFH), verdict of 3 March 2010, I R 8/09, BStB1. II 2010,502 , concerning mediation activities of statutory health insurance companies.

28 cf. Meier, Semelka (n 20) para 4 Corporation Tax Act / KStG, m.n. 25.

${ }^{29}$ cf. German Federal Finance Court (BFH), verdict of 11 January 1979, V R 26/74, BStB1. II 1979, 746 and German Federal Finance Court (BFH), verdict of 14 April 1983, V R 3/79, BStB1. II 1983, 491.

${ }^{30}$ cf. sec 4.1 (5) sentence 4, 5 Corporation Tax Guidelines 2015 (KStR 2015) - however, the legal entity of public law (1.e.p.l.) may assert a competition situation even if the actual amount falls below this benchmark. 
(sovereign operations) ${ }^{31}$, expressly do not constitute a BgA. The exercise of public authority is typically understood to describe an activity that is reserved for the legal entities of public law (1.e.p.l.) by custom and by law. ${ }^{32}$ One feature is the performance of public law functions deriving from governmental authority and serving governmental purposes. ${ }^{33}$ Compulsory acceptance due to a legal or official order $^{34}$ may also be considered to represent a characteristic of sovereign authority ${ }^{35}$. As a matter of principle, different activities of the legal entity of public law (1.e.p.1.) must be evaluated separately (cf. sec 4.1 (3) sentence 1 Corporation Tax Guidelines 2015 (KStR 2015).

If an area of activity has the characteristics of both sovereign activity and economic activity, the primary intended use for sovereign purposes should be emphasised. This is the case if the areas of activity are intertwined to the extent that precise delimitation is neither possible nor reasonable. In other words, the economic activity must be integrally linked to the sovereign activity and constitute a form of ancillary activity within the framework of the inherently sovereign activity. The inclusion of an intrinsically commercial activity in a sovereign operation alone is not sufficient to satisfy this criterion; the activities must be evaluated separately. ${ }^{36}$

"However, the exercise of public authority is excluded to the extent that the bodies of the entity participate in the free economy and perform an activity whose content is not materially different to that of the activity of a private commercial enterprise. ${ }^{137}$ As the provisions of state law also apply, different evaluations may arise at state level in individual cases. ${ }^{38}$ The

\footnotetext{
31 For information on trade tax treatment, see para $2 \sec 2$ of the Regulation on the Implementation of the German Trade Tax Act (GewStDV) - Sovereign operations are not classified as commercial operations.

32 cf. German Federal Ministry of Finance (BMF), circular of 11 December 2009, IV C 7 S 2706/07/10006, BStB1. I 2009, 1597 under I.1.a) Assignment on the basis of federal law, state law, or state law based on federal law with compulsory usage under public law; example: sewage disposal.

33 cf. German Federal Finance Court (BFH), verdict of 21 November 1967, I 274/64, BStB1. II 1968, 218.

34 cf. German Federal Finance Court (BFH), verdict of 25 January 2005, I R 63/03, BStB1. II 2005, 501 and sec 4.4 (1) sentence 1 Corporation Tax Guidelines 2015 (KStR 2015).

${ }^{35}$ For example, the operation of parking meters under the terms of road traffic regulations is considered to be a sovereign activity, whereas the provision of off-street parking spaces in multi-storey car parks, underground car parks, or continuous parking areas is considered to be an economic activity (cf. sec 4.5 (4) Corporation Tax Guidelines 2015 (KStR 2015) and sec 4.5 Corporation Tax Information 2015 (KStH 2015), "Parking space management"). Sovereign activities also include household waste disposal (cf. sec 4.5 (6) Corporation Tax Guidelines 2015 (KStR 2015) and funeral services (cf. sec 4.5 Corporation Tax Information 2015 (KStH 2015), "Cemetery administration, grave maintenance etc.").

36 cf. German Federal Finance Court (BFH), verdict of 26 May 1977, V R 15/74, BStB1. II 1977, 813 - Verdict relating to a cemetery administration that performed grave maintenance services and arrangement and support services for private funerals in addition to the sovereign function of funeral services.

${ }^{37}$ cf. German Federal Finance Court (BFH), verdict of 12 July 2012, I R 106/10, BStB1. II. 2012, 837, m.n. 9 - Municipal nursery schools are not a sovereign operation even though the obligation to ensure the provision of childcare is regulated by law.

38 cf. Meier, Semelka (n 20) para 4 Corporation Tax Act / KStG, m.n. 71. cf. German Federal Finance Court (BFH), verdict of 29 October 2008, I R 51/07, BStB1. II 2009, 1022

- The verdict addresses the issue of sovereign operations by reference to the example of a
} 
evaluation must be based on the principles of equal taxation, fair competition and preventing the distortion of competition.

\subsection{EXCEPTION: PARTICIPATING INTERESTS IN COMPANIES}

In addition to performing activities in its own right, a legal entity of public law (1.e.p.l.) may hold participating interests in forms of private law company to the extent that this is permitted by law. This includes interests in both partnerships ${ }^{39}$ and corporations ${ }^{40}$. If a legal entity of public law (1.e.p.l.) holds a participating interest in a commercial partnership ${ }^{41}$, the opinion of the German Federal Finance Court $^{42}$ is that this always constitutes the formation of a $\mathrm{BgA}$. In contrast, the authorities do not consider a participating interest in a corporation to constitute the formation of a $\mathrm{BgA}$ unless the legal entity of public law (1.e.p.l.) actually exercises an influence on the management of the corporation ${ }^{43}$ or the legal criteria for a company split are fulfilled. However, participating interests in companies that are solely involved in asset management do not give rise to a $\mathrm{BgA}{ }^{44}$ Irrespective of the existence of a $\mathrm{BgA}$, the income generated by the

municipal crematorium. See also German Federal Ministry of Finance (BMF), circular of 11 December 2009, loc. cit., I.1.b) The operation of a crematorium by a legal entity of public law (1.e.p.1.) without compulsory usage under public law does not constitute a sovereign operation $(\mathrm{BgA})$.

${ }^{39}$ This relates primarily to the legal forms of the "Gesellschaft bürgerlichen Rechts" or "GbR" (civil law partnership; para $705 \mathrm{ff}$. of the German Civil Code (BGB), the "offene Handelsgesellschaft" or "OHG" (general partnership; para 105 ff. of the German Commercial Code (HGB) and the "Kommanditgesellschaft" or "KG" (limited partnership, including the special form of the $\mathrm{GmbH} \& \mathrm{Co}$. KG; para $161 \mathrm{ff}$. HGB).

${ }^{40}$ This relates in particular to the legal forms of the "Aktiengesellschaft" or "AG" (stock corporation in accordance with the German Stock Corporation Act (AktG) and "Gesellschaft mit beschränkter Haftung" or "GmbH" (limited liability company in accordance with the German Limited Liability Companies Act (GmbHG).

${ }^{41}$ Income tax law also refers to a "partnership" within the meaning of para $15 \mathrm{sec} 1$ sentence 1 no 2 Income Tax Act / EStG.

42 cf. German Federal Finance Court (BFH), verdict of 25 March 2015, I R 52/13, BStB1. II 2016, 172, m. n. 19. In its circular of 8 February 2016 (IV C 2 - S 2706/14/10001, BStB1 I 2016, 237), the German Federal Ministry of Finance (BMF) instructs the fiscal authorities to apply the grounds for the verdicts without restriction only up to and including the 2008 assessment period. A further circular is to be issued for assessment periods from 2009 onwards. The authorities are likely to be particularly disturbed by the BFH's finding that a participating interest in a partnership gives rise to a $\mathrm{BgA}$ even if the activity would not constitute the formation of a BgA if it were performed directly by the legal entity of public law (1.e.p.1.) (the verdict in question related to a waste management centre with the legal form of a $\mathrm{GmbH} \& \mathrm{Co}$. KG; waste disposal may constitute a sovereign activity depending on the circumstances).

43 cf. sec 4.1 (2) sentences 2-5 Corporation Tax Guidelines 2015 (KStR 2015). A small participating interest may be sufficient to assume the existence of a BgA if control and influence are exercised jointly with other legal entities of public law (1.e.p.1.). According to these criteria, participating interests in municipal public utilities would typically give rise to a $\mathrm{BgA}$, for instance.

44 cf. Meier, Semelka (n 20) para 4 Corporation Tax Act / KStG, marginal no 29 for partnerships; sec 4.1 (2) sentence 5 Corporation Tax Guidelines 2015 (KStR 2015) for corporations. 
corporation itself is taxable in accordance with the general provisions of the German Corporation Tax Act. ${ }^{45}$

\section{TAXATION OF INCOME}

\subsection{TyPe OF InCOME AND Profit Determination}

The income of a BgA always constitutes commercial income within the meaning of para 15 Income Tax Act (EStG) even if the BgA is leased. ${ }^{46}$ In the case of commercial income, taxation is based on the profit generated. In accordance with para $4 \mathrm{sec} 1$ sentence 1 in conjunction with para 5 Income Tax Act (EStG), profit is calculated by comparing the operating assets of an entity at the start and end of the reporting period. If there is no statutory obligation for the entity to keep accounts and regularly prepare financial statements, a simplified method of profit determination using the cash method of accounting within the meaning of para 4 sec 3 Income Tax Act (EStG) may be applied. Non-fiscal obligations to keep accounts and regularly prepare financial statements also apply for tax law (cf. para 140 of the German Fiscal Code (AO). In a specific case, for example, such an obligation may arise from the provisions of the $\mathrm{HGB}^{47}$ or the state regulations on municipal enterprises ${ }^{48}$. As a matter of principle, the obligation to perform double-entry bookkeeping ${ }^{49}$ does not exclude the possibility of applying the cash method of accounting. An obligation for solely tax-related purposes is possible if the thresholds set out in para 141 $\mathrm{AO}$ are exceeded. For the purposes of profit/income determination, a legally dependent $\mathrm{BgA}$ is notionally separated from the legal entity of public law (1.e.p.l.) to the extent that agreements such as rental and lease agreements between the jPöR and the $\mathrm{BgA}$ are fundamentally recognised, albeit subject to the restrictive conditions applicable to controlling shareholders under corporation tax law. ${ }^{50}$

\footnotetext{
45 cf. sec 4.1 (7) Corporation Tax Guidelines 2015 (KStR 2015).

46 cf. German Federal Finance Court (BFH), verdict of 1 August 1979, I R 106/76, BStB1. II 1979, 716. For information on leased BgAs, see also para 4 sec 4 Corporation Tax Act / KStG. The assumption of commercial income at all times corresponds to the treatment of other taxpayers with unlimited tax liability; see para $8 \mathrm{sec} 2$ Corporation Tax Act / KStG.

${ }^{47}$ cf. Klaus J. Hopt in Adolf Baumbach, Klaus J. Hopt, Handelsgesetzbuch, Verlag C.H. Beck, 36th ed., Munich 2014, para 1 m.n. 27 - Entities required to keep accounts include Deutsche Bundesbank, savings banks and public insurance companies.

48 e.g. arising from para $11 \mathrm{sec} 1$ sentence 3 SächsEigBVO in the case of the Free State of Saxony.

${ }^{49}$ e.g. arising from para $72 \mathrm{sec} 2$ sentence $2 \mathrm{SächsGemO}$ in the case of the Free State of Saxony; cf. BMF, circular of 3 January 2013, IV C 2 - S 2706/09/10005, BStB1 I 2013, 59 (including with regard to the special features of regulations on municipal enterprises).

50 cf. sec 8.2 (1) and (2) Corporation Tax Guidelines 2015 (KStR 2015), sec 8.2 Corporation Tax Information 2015 (KStH 2015), "Rental and lease agreements" and "Agreements".
} 


\subsection{Special Features for Legal Entities of Public Law}

In accordance with para $23 \mathrm{sec} 1$ Corporation Tax Act (KStG), the income generated by a $\mathrm{BgA}$ is initially subject to a tax rate of $15 \%$. To ensure equal tax treatment with the free economy, however, the economic benefits gained by the legal entity of public law (1.e.p.l.) as a result of the $\mathrm{BgA}$ must also be taxed. If a $\mathrm{GmbH}$ were to distribute taxable profits to its shareholders, for example, this profit distribution would also be taxable as income from capital assets at the level of the shareholders in accordance with para $20 \mathrm{sec} 1$ no 1 Income Tax Act (EStG). Income tax law achieves a similar effect for the taxation of legal entities of public law (1.e.p.1.) through the provisions of para $20 \mathrm{sec} 1 \mathrm{no} 10 \mathrm{a}$ and $\mathrm{b}$ Income Tax Act $(\mathrm{EStG})^{51}$ that were introduced as a result of the German Tax Reduction Act ${ }^{52}$. The legal entity of public law (l.e.p.1.) has limited tax liability in accordance with para 2 no 2 Corporation Tax Act (KStG) for this income, which is subject to withheld capital gains tax in accordance with para $43 \mathrm{sec} 1$ sentence 1 no $7 \mathrm{~b}$ and no 7c Income Tax Act (EStG). The withholding of capital gains tax is limited to $15 \%$ in accordance with para 43 a sec 1 sentence 1 no 2 Income Tax Act (EStG), thereby corresponding to the corporation tax rate set out in para $23 \mathrm{sec} 1$ Corporation Tax Act (KStG). The withheld tax is definitive in accordance with para $32 \mathrm{sec} 1$ no 2 Corporation Tax Act (KStG).

\section{The VAT TREATMENT OF LEGAL ENTITIES GOVERnED BY Public Law}

\section{Pressure for NeW Legislation}

In addition to the general conditions for classification as an entrepreneur in accordance with para $2 \mathrm{sec} 1$ Value Added Tax Act (Umsatzsteuergesetz, UStG for short), which also apply to legal entities of public law (1.e.p.l.), to date the treatment of legal entities of public law (1.e.p.1.) for value-added tax purposes has been based in particular on para 2 sec 3 sentence 1 Value Added Tax Act (UStG). According to this provision, a legal entity of public law (1.e.p.1.) performed commercial or professional activities within the meaning of para $2 \mathrm{sec} 1$ Value Added Tax Act (UStG) only within the framework of its commercial operations (BgA) and agricultural and forestry operations. The existence of a $\mathrm{BgA}$ was subject solely to corporation tax criteria (cf. para $1 \mathrm{sec} 1$ no 6, para 4 Corporation Tax Act (KStG). This resulted in exemption from VAT for activities that, in themselves, were very much performed in competition with the free economy but that were not treated as such on account of the $\mathrm{BgA}$ criteria. This related to asset management activities performed by legal entities of public law (1.e.p.l.) as well as assistance services provided between legal entities of public law (1.e.p.1.). Even bodies that were not economically

\footnotetext{
${ }^{51}$ For further information cf. German Federal Ministry of Finance (BMF), circular of 9 January 2015, IV C 2 - S 2706a/13/10001, BStB1. I 2015, 111.

52 German Act on the Reduction of Tax Rates and Reform of Business Taxation (StSenkG) of 23 October 2000, BGB1. I 2000, 1433.
} 
distinct within the overall activity of the legal entity of public law (1.e.p.l.) ${ }^{53}$ were exempt from VAT as a result.

However, this treatment did not necessarily result in a tax benefit. As entrepreneur status also provides the option of input tax deduction, VAT may even be the more economically attractive variant for investments in particular. As such, it comes as no surprise to learn that the German Federal Finance Court (BFH) ${ }^{54}$ has found itself having to address the VAT treatment of legal entities of public law (1.e.p.l.) in Germany to a growing extent in recent years; this also involves taking into account the judgements issued by the European Court of Justice (ECJ) ${ }^{55}$.

The fact that, by reference to the provisions of art 13 of the Directive on the VAT System ${ }^{56}$, the national evaluation of entrepreneur status based on corporation tax criteria is not supported in EU law should not come as a surprise. As such, it can also be concluded that this connection is ultimately no longer relevant based on the BFH's case law. ${ }^{57}$ According to the $\mathrm{BFH}$, the evaluation should be based primarily on the form taken by the legal entity of public law`s (l.e.p.l.) activity. If a legal entity of public law (1.e.p.l.) acts on a private law basis, it is treated as an entrepreneur; by contrast, if its activity has a basis in public law, a legal entity of public law (1.e.p.l.) is treated as an entrepreneur only if it enters into competition with other providers. This case law was not generally applied by the authorities. Instead, the legal entity of public law (l.e.p.l.) was merely given the option of invoking the more favourable scenario; however, this would then be required to be applied uniformly for all of its activities. In practice, this meant that taxation was able to follow either the strict wording of national legislation or its interpretation in case law.

\footnotetext{
53 cf. sec 4.1 (5) sentence 1 Corporation Tax Guidelines 2015 (KStR 2015) - The current threshold for examining this criterion is annual revenue of EUR 35,000 (see also sec 3.4.5). 54 cf. e.g. German Federal Finance Court (BFH), verdict of 15 April 2010, V R 10/09, UR 2010, 646 (permission for the installation of vending machines by a university); German Federal Finance Court (BFH), verdict of 3 March 2011, V R 23/10, BStB1. II 2012, 74 (costs of marketplace renovation); German Federal Finance Court (BFH), verdict of 10 November 2011, V R 41/10, UR 2012, 272 (plaintiff: a municipality in the Free State of Saxony / known as the "sports hall verdict").

55 cf. e.g. ECJ, verdict of 14 December 2000, C-446/98 "Fazende Publica", UR 2001, 108; ECJ, verdict of 16 September 2008, C-288/07 "Isle of Wight Council", IStR 2008, 734; ECJ, verdict of 4 June 2009, C-102/08 "Salix Grundstücks-Vermietungsgesellschaft", BFH/NV 2009, 1222; ECJ, verdict of 29 October 2015, C-174/14 "Saudacor", UR 2015, 901.

56 Council Directive 2006/112/EC of 28 November 2006, ABl. no L 347 2006, 1 (previously: art 4 (5) of Sixth Council Directive 77/388/EEC of 17 May 1977 on the Harmonisation of the Laws of the Member States relating to Turnover Taxes (ABl. no L $1451977,1)$.

57 For further information cf. Pierre Frotscher, 'Umsatzbesteuerung der Kommunen Rechtliche Rahmenbedingungen in der EU und im nationalen Recht sowie aktuelle Entwicklungen in der Rechtsprechung (2013) 4 Sachsenlandkurier 254 et seq.
} 


\section{NEW LEGISLATION}

\subsection{GeneraL}

The introduction of para $2 \mathrm{~b}$ Value Added Tax Act (UStG) as a result of the German Tax Amendment Act $2015^{58}$ represented the legislator's response to the case law established by the courts and the need for the national statutory provisions on the VAT treatment of the public sector to be adapted to reflect EU law. ${ }^{59}$ Paragraph $2 \mathrm{~b}$ sec 1 Value Added Tax Act (UStG) clearly incorporates the provisions of art $13 \mathrm{sec} 1$ of the Directive on the VAT System. As a result, the previous connection between VAT and corporation tax law no longer applies. In future, classification as an entrepreneur will be based solely on VAT criteria. Doubts have been raised as to the conformity of the new provision with EU law to the extent that para $2 b$ sec 2 and sec 3 Value Added Tax Act (UStG) supplements the general provision in para $2 \mathrm{~b}$ sec 1 Value Added Tax Act (UStG) with definitions of the concept of "significant distortion of competition" that are not based on the Directive on the VAT System in this form. As such, the new provision can be expected to be the subject of case law sooner or later, particularly at the level of the ECJ. ${ }^{60}$ In addition to the issue of EU law, it is especially notable that the legislator has used a number of indeterminate legal concepts in formulating the new legislation. Based on past experience, this tends to lead to substantially greater scope for interpretation. Accordingly, the authorities are currently preparing a circular on application that will address material legal questions of interpretation; this is expected to be published by the end of 2016 by all accounts.

\subsection{ENTREPRENEUR STATUS}

The classification of a legal entity of public law (1.e.p.1.) as an entrepreneur is initially based on the general criteria of para 2 sec 1 Value Added Tax Act (UStG). These state that a legal entity of public law (1.e.p.1.) is classifiable as an entrepreneur if it performs economic activities, i.e. independent, sustainable activities with the intention of generating income. An exception is granted by para $2 \mathrm{~b}$ sec 1 sentence 1 Value Added Tax Act (UStG), which states that a legal entity of public law (1.e.p.1.) performing activities in the exercise of public authority is not classifiable as an entrepreneur. Activities are performed in the exercise of public authority if they are based on a special provision of public law, e.g. an act of law, a legislative decree, an international treaty or special provisions of canon

\footnotetext{
${ }^{58}$ Introduced by art 12 no 3 of the German Tax Amendment Act 2015 (StÄndG 2015), legislation of 2 November 2015, BGB1. I 2015, 1834.

59 cf. Bundestag printed paper 18/6094 of 23 September 2015 - Recommended resolution and report of the Finance Committee, 91.

${ }^{60} \mathrm{cf}$. Hans-Herrmann Heidner, 'VAT treatment of the public sector - consequences of case law for the new legislation in para 2b Value Added Tax Act (UStG)' (2016) 2 Umsatzssteuer-Rundschau 45 et. seq. - significant distortion of competition is an autonomous concept of EU law.
} 
law. ${ }^{61}$ If treatment as a non-entrepreneur results in significant distortion of competition, however, the legal entity of public law (1.e.p.l.) must be treated as an entrepreneur in accordance with para $2 \mathrm{~b} \mathrm{sec} 1$ sentence 2 Value Added Tax Act (UStG).

The work establishments of a penal institution serve as a good example of the effect of para 2b Value Added Tax Act (UStG). Based on the judgements issued by the $\mathrm{BFH}^{62}$, the work establishments of a penal institution do not constitute economic activity, but rather are considered to be sovereign operations ${ }^{63}$ as the employment of prisoners forms part of the penal system. As such, this does not result in the formation of a $\mathrm{BgA}$ in accordance with para $4 \mathrm{sec} 5$ sentence 1 Corporation Tax Act (KStG) and no entrepreneurial activity is performed in accordance with para $2 \mathrm{sec} 3$ sentence 1 Value Added Tax Act (UStG; old version). If the matter is evaluated in accordance with para $2 \mathrm{~b}$ sec 1 sentence 1 Value Added Tax Act (UStG), it remains the case that the activities are performed in the exercise of public authority; however, the circumstances described in para $2 \mathrm{~b}$ sec 1 sentence 2 Value Added Tax Act (UStG) are clearly met in respect of the services provided by a modern penal institution, which range from stainless steel barbecues and smoker grills to nesting boxes, small bottle cases and children's toys ${ }^{64}$, all of which are currently advertised online as "VATexempt".

These activities on the basis of public law, which could potentially be VAT-exempt, must be distinguished from activities on the basis of private law. Activities of this nature are already excluded from the scope of para $2 \mathrm{~b}$ sec 1 Value Added Tax Act (UStG) and hence must be evaluated solely in accordance with the criteria of para 2 sec 1 Value Added Tax Act (UStG). In this respect, the new legislation systematically reflects the case law established by the BFH and the ECJ.

\subsection{GENERAL EXCLUSIONS FROM SigNifiCANT DistorTION OF COMPETITION}

In accordance with para $2 \mathrm{~b} \sec 2$ no 1 Value Added Tax Act (UStG), significant distortion of competition does not exist if the (annual) revenue generated by a legal entity of public law (l.e.p.l.) from similar activities is not expected to exceed EUR 17,500. This is an irrebuttable legal presumption. Annual revenue in relation to this threshold must be forecast at the start of the year. The definition of what exactly is meant by "similar" has a considerable influence on actual taxation, and hence is likely to occupy the courts. The effect of this provision must be scrutinised, as the threshold could be utilised multiple times if different activities are performed. For example, if a legal entity of public law (l.e.p.l.) has four separate areas of

\footnotetext{
${ }^{61} \mathrm{cf}$. Bundestag printed paper 18/6094 of 23 September 2015 - Recommended resolution and report of the Finance Committee, 91.

${ }^{62}$ cf. German Federal Finance Court (BFH), verdict of 14 October 1964, I 80/62 U, BStB1. III 1965,95 .

63 cf. Meier, Semelka (n 20) para 4 Corporation Tax Act / KStG, m.n. 76 "Work establishments of penal institutions".

${ }^{64} \mathrm{cf}$. The product range of the penal institutions of Lower Saxony state at https://jvashop.de.
} 
activity, it may arrange for revenue of up to EUR 70,000 p.a. to be taxexempt. This would significantly exceed the maximum permitted taxexempt total revenue of EUR 17,500 for small entrepreneurs. ${ }^{65}$

In addition, para $2 \mathrm{~b}$ sec 2 no 2 Value Added Tax Act (UStG) states that there is no significant distortion of competition if similar services performed on the basis of private law are tax-exempt without right of waiver in accordance with para 9 Value Added Tax Act (UStG). This provision relates to an area in which there are no concerns of distortion of competition from a VAT perspective, as a potential competitor would also be nonoptionally exempt from VAT. However, this explicitly excludes activities covered by the optional tax liability provided by para 9 Value Added Tax Act (UStG). To this extent, a legal entity of public law (1.e.p.1.) should also be able to benefit from input tax deduction by exercising the option provided by para 9 Value Added Tax Act (UStG), thereby preventing itself from being subject to a competitive disadvantage ${ }^{66}$. In practice, this is likely to apply primarily to the letting of land or buildings, which is fundamentally tax-exempt in accordance with para 4 no 12 a Value Added Tax Act (UStG; with no entitlement to deduct input tax in accordance with para $15 \mathrm{sec} 1$ and sec 2 no 1 Value Added Tax Act (UStG), but for which an option is fundamentally provided by para $9 \mathrm{sec} 1$ Value Added Tax Act (UStG) (with input tax deduction e.g. for investment costs in buildings in accordance with para $15 \mathrm{sec} 1$ Value Added Tax Act (UStG).

\subsection{Services Provided to Other Legal Entities of Public LAW}

With specific reference to services provided between legal entities of public law (1.e.p.1.), para 2b sec 3 Value Added Tax Act (UStG) describes additional exceptional situations in which there is not assumed to be any significant distortion of competition, meaning that no VAT is levied. According to the grounds of the legislation ${ }^{67}$, the provisions are justified in light of demographic change, the shortfall in public funds and the leveraging of synergy effects by harnessing the existing material and human resources to minimise costs and hence reduce the burden on citizens. The provisions relate to sovereign functions as well as public welfare services, particularly in the area of inter-municipality cooperation.

If the statutory provisions mean that services can be performed by legal entities of public law (l.e.p.l.) only, there is no competition with other providers. Accordingly, para $2 \mathrm{~b}$ sec 3 no 1 Value Added Tax Act (UStG) states that there can be no significant distortion of competition in such cases. The essence of para $2 \mathrm{~b}$ sec 1 sentence 1 Value Added Tax Act (UStG), namely that the exercise of public authority does not involve entrepreneurial activity, therefore applies accordingly. The examples cited in the grounds of the legislation ${ }^{68}$ include joint administrative districts for registry offices and

\footnotetext{
${ }^{65}$ cf. para $19 \mathrm{sec} 1$ sentence 1 and (3) Value Added Tax Act (UStG).

${ }^{66}$ cf. Bundestag printed paper 18/6094 of 23 September 2015 - Recommended resolution and report of the Finance Committee, 91.

67 ibid.

${ }^{68}$ ibid, 92.
} 
public order offices or the activities of joint local residents' registration offices. However, there is some doubt as to how apposite these examples really are. If two municipalities establish a "joint" registry office, for example, this formulation suggests that the expenses of establishing the registry office are shared between the parties. At first glance, at least, it is therefore not immediately obvious as to where there is supposed to be a potential exchange of services requiring prevention by way of a provision such as para $2 \mathrm{~b}$ sec 3 no 1 Value Added Tax Act (UStG).

Paragraph $2 \mathrm{~b} \sec 3$ no 2 Value Added Tax Act (UStG) of the new legislation undoubtedly provides the greatest scope in terms of interpretation. This provision states that there is no significant distortion of competition even if the cooperation is determined by shared public interests. This is typically the case if the criteria set out in para $2 b \sec 3$ no 2 sentence 2 a to d Value Added Tax Act (UStG) are fulfilled: a) the service provision has a long-term basis in public law (e.g. public contract, international treaty; question: what constitutes "long-term"?), b) it involves the maintenance of public infrastructure and the performance of a public function that is incumbent upon all parties (e.g. technical infrastructure or education), c) it is remunerated solely in the form of cost reimbursement (how is this determined, not least since it tends to be unlikely that cost accounting is performed with the required depth?) and d) services are provided primarily to other legal entities of public law (l.e.p.l.) (question: what constitutes "primarily"?). The grounds of the legislation ${ }^{69}$ state relatively succinctly that the aforementioned criteria are based on EU public procurement law. However, the provisions of public procurement law are supposed to apply only to the extent that they are compatible with the Directive on the VAT System.

It is clear to see that the provisions of para $2 \mathrm{~b} \sec 3$ no 2 Value Added Tax Act (UStG) provide a legal entity of public law (1.e.p.1.) with significant leeway while simultaneously entailing a not insubstantial risk of a different interpretation in case law to that which was applied in concluding the respective agreements. ${ }^{70}$ In addition, there may be an issue in terms of distortion of competition due to the exclusion of other market participants.

\subsection{Catalogue of Entrepreneurial Activities}

In nos 1-4, para 2b sec 4 Value Added Tax Act (UStG) starts by reproducing the catalogue of public-sector activities that are always considered to be entrepreneurial as set out in the old version of para $2 \sec 3$ sentence 2 Value Added Tax Act (UStG). The catalogue is supplemented by a reference in para $2 \mathrm{~b}$ sec 4 no 5 Value Added Tax Act (UStG) to Annex I to the Directive on the VAT System (cf. art $13 \mathrm{sec} 1$ para 3 of the Directive on the VAT System). The extended scope of the new legislation is likely to remain manageable, as the activities listed in Annex I are also considered to have been typically taxable as BgAs under the previous legislation.

\footnotetext{
69 ibid.

${ }^{70}$ cf. Heidner (n 62) 45 et seq.
} 


\section{Transitional Arrangement and Optional APPLICATION}

The new version of para $2 b$ Value Added Tax Act (UStG) came into force on 1 January $2016^{71}$; according to para $27 \sec 22$ sentence 1 Value Added Tax Act (UStG ${ }^{72}$ ), however, it is applicable for the first time only to revenue generated after 31 December 2016. This gives a legal entity of public law (1.e.p.1.) just under a year to adapt to the new legal conditions.

Furthermore, para $27 \mathrm{sec} 22$ sentence 3 Value Added Tax Act (UStG) provides legal entities of public law (1.e.p.l.) with the option of submitting a declaration to the tax office stating that they intend to apply para $2 \mathrm{sec} 3$ Value Added Tax Act (UStG) in the version in force on 31 December 2015 to all revenue generated after 31 December 2016 and before 1 January 2021. This declaration must be submitted by 31 December 2016 at the latest (cf. para $27 \mathrm{sec} 22$ sentence 5 Value Added Tax Act (UStG). The declaration may be revoked at a later date with effect from the start of a subsequent calendar year (cf. para 27 sec 22 sentence 6 Value Added Tax Act (UStG). ${ }^{73}$

If a legal entity of public law (1.e.p.l.) exercises this option, it will continue to be taxed in accordance with the existing legislation. This means that asset management activities and assistance services will remain taxexempt until 31 December 2020 at the latest. The exercise of this option is intended to allow legal entities of public law (1.e.p.l.) to extend the one-year transitional period provided by para $27 \mathrm{sec} 22$ sentence 1 Value Added Tax Act (UStG) for up to a further four years in order to enable an orderly transition to the new taxation system. ${ }^{74}$ As there is currently considerable uncertainty with regard to the consequences of applying the new standard from 2017, not least as a result of the large number of indeterminate legal concepts contained in para $2 \mathrm{~b}$ Value Added Tax Act (UStG), many legal entities of public law (1.e.p.1.) are expected to initially exercise the option in order to give themselves more time to intensively examine the individual steps that will be required to adapt to the new legal situation ${ }^{75}$.

\section{SUMMARY}

The public sector in Germany is subject to both income tax and value-added tax when its activities go beyond the area of public administration to the extent that they enter into competition with other providers. The taxation of public-sector entities is intended primarily to prevent the distortion of competition. The delimitation of the spheres that

\footnotetext{
${ }^{71} \mathrm{cf}$. art 18 sec 4 StÄndG 2015.

72 Introduced by art 12 no 6 StÄndG 2015.

73 cf. German Federal Ministry of Finance (BMF), circular of 19 April 2016, III C 2 - S $7106 / 07 / 10012-06$, BStB1. I 2016, 986 - on the application of the transitional arrangement provided by sec 27 (22) Value Added Tax Act (UStG).

74 cf. Bundestag printed paper 18/6094 of 23 September 2015 - Recommended resolution and report of the Finance Committee, 93.

${ }^{75}$ For further information cf. Fritz Lang, 'The new VAT legislation for legal entities governed by public law in accordance with para 2b Value Added Tax Act (UStG) - to exercise the option or not to exercise?' (2016) 4 Sachsenlandkurier 186 et seq.
} 
are relevant for taxation purposes requires a complex system of statutory provisions. The German Tax Amendment Act 2015 seeks to establish a new statutory basis for the VAT treatment of the public sector that is compliant with EU law.

\section{References}

Frotscher Gerrit in Frotscher Gerrit, Drüen Klaus-Dieter, Corporation Tax Act (Haufe-Lexware GmbH \& Co. KG 2008)

Frotscher Marion in Frotscher Gerrit, Drüen Klaus-Dieter, German Trade Tax Act / GewStG (Haufe-Lexware GmbH \& Co. KG 2012)

Frotscher Pierre, 'Taxation of the Public Sector' (2013) 4 Sachsenlandkurier Heidner Hans-Herrmann, 'VAT treatment of the public sector consequences of case law for the new legislation in para $2 b$ Value Added Tax Act (UStG)' (2016) 2 Umsatzsteuer-Rundschau

Hopt Klaus J. in Baumbach Adolf, Hopt Klaus J., Handelsgesetzbuch (Verlag C.H. Beck 2014)

Lang Fritz, 'The new VAT legislation for legal entities governed by public law in accordance with para $2 b$ Value Added Tax Act (UStG) - to exercise the option or not to exercise?' (2016) 4 Sachsenlandkurier

Meier Norbert, Semelka Thomas in Herrmann Carl, Heuer Gerhard, Raupach Arndt, Income Tax Act (EStG)/Corporation Tax Act (KStG) (Verlag Dr. Otto Schmidt KG Köln 2006)

Schallmoser Ulrich in Herrmann Carl, Heuer Gerhard, Raupach Arndt, Income Tax Act (EStG)/Corporation Tax Act (KStG) (Verlag Dr. Otto Schmidt KG Köln 2006)

Witt Sven-Christian in Herrmann Carl, Heuer Gerhard, Raupach Arndt, Income Tax Act (EStG)/Corporation Tax Act (KStG) (Verlag Dr. Otto Schmidt KG Köln 2006) 